\title{
Novel variants of HMW glutenin subunits from Aegilops section Sitopsis species in relation to evolution and wheat breeding
}

\author{
Qian-Tao Jiang ${ }^{1}$, Jian Ma ${ }^{1}$, Yu-Ming Wei ${ }^{1}$, Ya-Xi Liu', Xiu-Jin Lan' ${ }^{1}$, Shou-Fen Dai ${ }^{1}$, Zhen-Xiang Lu²*, Shan Zhao ${ }^{1}$, \\ Quan-Zhi Zhao ${ }^{1}$ and You-Liang Zheng ${ }^{3^{*}}$
}

\begin{abstract}
Background: High molecular weight glutenin subunits (HMW-GSs), encoded by the genes at Glu-1 loci in wheat and its related species, are significant in the determination of grain processing quality. However, the diversity and variations of HMW-GSs are relatively low in bread wheat. More interests are now focused on wheat wild relatives in Triticeae. The genus Aegilops represents an important germplasm for novel HWM-GSs and other useful genes for wheat genetic improvement.

Results: Six novel Glu-1 alleles and HMW-GSs were identified and characterized from three species of Aegilops section Sitopsis (S genome). Both open reading frames (ORFs) and promoter regions of these Glu-1 alleles were sequenced and characterized. The ORFs of Sitopsis Glu-1 genes are approximately $2.9 \mathrm{~kb}$ and $2.3 \mathrm{~kb}$ for x-type and $y$-type subunits, respectively. Although the primary structures of Sitopsis HMW-GSs are similar to those of previously reported ones, all six x-type or $y$-type subunits have the large fragment insertions. Our comparative analyses of the deduced amino acid sequences verified that Aegilops section Sitopsis species encode novel HMW-GSs with their molecular weights larger than almost all other known HMW-GSs. The Glu-1 promoter sequences share the high homology among $\mathrm{S}$ genome. Our phylogenetic analyses by both network and $\mathrm{NJ}$ tree indicated that there is a close phylogenetic evolutionary relationship of $\mathrm{x}$-type and $\mathrm{y}$-type subunit between $\mathrm{S}$ and $\mathrm{D}$ genome.

Conclusions: The large molecular weight of HMW-GSs from S genome is a unique feature identified in this study. Such large subunits are resulted from the duplications of repetitive domains in Sitopsis HMW-GSs. The unequal crossover events are the most likely mechanism of variations in glutenin subunits. The $\mathrm{S}$ genome-encoded subunits, 1Dx2.2 and 1Dx2.2* have independent origins, although they share similar evolutionary mechanism. As HMW-GSs play a key role in wheat baking quality, these large Sitopsis glutenin subunits can be used as special genetic resources for wheat quality improvement.
\end{abstract}

\section{Background}

High molecular weight glutenin subunits (HMW-GSs) are important storage proteins in seed endosperms of wheat and its related species $[1,2]$. Due to their composition effects on the elasticity of wheat dough, HMW-GSs play a significant role in the determination of grain processing quality [3]. HMW-GSs are encoded by the genes

\footnotetext{
* Correspondence: zhen-xiang.lu@agr.gc.ca; ylzheng@sicau.edu.cn

${ }^{2}$ Lethbridge Research Centre, Agriculture and Agri-Food Canada, Lethbridge

T1J 4B1, Canada

${ }^{3}$ Key Laboratory of Southwestern Crop Germplasm Utilization, Ministry of Agriculture, Sichuan Agricultural University, Ya'an, Sichuan 625014, China Full list of author information is available at the end of the article
}

at Glu-1 loci on the long arms of the Group 1 chromosomes (1A, 1B and 1D) in bread wheat. HMW-GSs can be further classified into two subfamilies ( $x$-type and $y$ type), which are thought to have arisen from gene duplication events. Single copy of $x$-type and y-type gene occurs at two tightly linked loci, Glu-1x and Glu-1y. The HMW-GSs encoded by Glu-1x or Glu-1y can be distinguished from each other by the difference in their peptide lengths $[1,4]$. Previous studies indicated that allelic polymorphism in wheat HMW-GSs is associated with variations in the gluten viscoelasticity and bread making quality [1]. Up to now, a number of Glu-1 alleles and HMW-GSs have been identified and characterized

\section{Biomed Central}


from wheat and its related species [5-18]. Sequence analyses of HMW-GS coding regions revealed that the primary structure of mature HMW-GSs consists of a central repetitive domain flanked by the conserved $\mathrm{N}$ terminal and $\mathrm{C}$-terminal regions [2]. The repetitive domain is mainly composed of repeat motifs including tripeptide, hexapeptide and nonapeptide. The difference among various HMW-GSs is mainly resulted from variable number of repeat motifs in the repetitive domains [2,19].

The section Sitopsis of genus Aegilops contains five species: Aegilops bicornis, (Forsskal) Jaub. \& Spach. $\left(\mathrm{S}^{\mathrm{b}} \mathrm{S}^{\mathrm{b}}, 2 \mathrm{n}=2 \mathrm{x}=14\right)$, Ae. longissima (Schweinf. \& Muschl.) Á. Löve. $\left(\mathrm{S}^{\mathrm{l}} \mathrm{S}^{\mathrm{l}}, 2 \mathrm{n}=2 \mathrm{x}=14\right)$, Ae. sharonensis (Eig) Á. Löve. $\left(\mathrm{S}^{\text {sh }} \mathrm{S}^{\mathrm{sh}}, 2 \mathrm{n}=2 \mathrm{x}=14\right)$, Ae. searsii, (Feldman \& Kislev ex Hammer) Á. Löve. $\left(S^{\mathrm{S}} \mathrm{S}^{\mathrm{s}}, 2 \mathrm{n}=2 \mathrm{x}=14\right.$ ) and Ae. speltoides, (Tausch) Á.Löve, (SS, $2 \mathrm{n}=2 \mathrm{x}=14$ ) [20]. Previous reports on cytogenetic and genetic investigations indicated that Aegilops genomes from this section of five species are closely related [21-24]. Although the characterization of HMW-GSs in two accessions of Ae. searsii have been reported [16], the Glu-1 alleles and HMW-GSs in other four Sitopsis species have not been investigated. Our preliminary study surveyed the expression of HMW-GSs in Ae. bicornis, Ae. longissima and Ae. sharonensis and realized that the Sitopsis Glu-1 alleles encodes the glutenin subunits with molecular weights much larger than other known HMW-GSs available in public databases. Here, we report the isolation and characterization of novel Glu-1 alleles and HMWGSs from Ae. bicornis, Ae. longissima and Ae. sharonensis. The objective of this study is to investigate the structural features of Sitopsis HMW-GSs, understand the evolutionary relationship of HWM-GS gene family within Triticeae, and further explore the potentials of $S$ genome-encoded HMW-GSs in wheat quality breeding.

\section{Results}

Identification of Aegilops HMW-GSs and Glu-1 alleles

The SDS-PAGE profiles on three accessions of Ae. bicornis, Ae. longissima and Ae. sharonensis indicated that Sitopsis HMW-GSs consist of large $\mathrm{x}$-type and $\mathrm{y}$-type subunits which migrate significantly slower than the same type of subunits in Chinese Spring (Figure 1a). Subsequent cloning of the Glu-1 ORFs further verified that the molecular weights of these Sitopsis x-type subunits are close to or larger than that of $1 \mathrm{Dx} 2.2$, one of largest HMW-GSs previously reported [25]. The results of $\mathrm{N}$-terminal sequencing suggested that the protein bands with slower and faster mobility are $\mathrm{x}$ - and $\mathrm{y}$-type subunits, respectively. The obtained sequences of seed protein are perfectly matched to those deduced from the cloned genes (Table 1).

The PCR amplicons of Sitopsis Glu-1 alleles are composed of two DNA fragments (approximately $2.9 \mathrm{~kb}$ and
$2.3 \mathrm{~kb}$ ) for each of three accessions (Figure 1b). All amplified PCR products were cloned and the Glu-1 ORFs at different alleles were determined by the sequence analysis and enzyme digestions. The full length of Glu-1 ORFs was obtained by using the method of primer walking and nested deletion. Six sequences for $\mathrm{x}$-type and $\mathrm{y}$-type HMW-GSs from the $\mathrm{S}$ genome of three Aegilops species were designated as $1 S^{\mathrm{b}} \times 2.9$ and $1 S^{\mathrm{b}} \mathrm{y} 2.3$ (Ae. bicornis), $1 S^{\mathrm{l}} \times 2.9$ and $1 S^{\mathrm{l}} \mathrm{y} 2.3$ (Ae. longissima), $1 S^{\mathrm{sh}} \mathrm{x} 2.9$ and $1 S^{\mathrm{sh}} \mathrm{y} 2.3$ (Ae. sharonensis), respectively. All these DNA sequences have been deposited into the NCBI database with the Genbank accession numbers from JN001481 to JN001486.

\section{Expression of $1 S^{\text {sh }} \times 2.9$ and $1 S^{\text {sh }}$ y2.3 in bacterial cells}

After removing the coding sequence for the signal peptide from the ORFs of $1 S^{\text {sh }} \times 2.9$ and $1 S^{\text {sh }} y 2.3$, the modified ORFs were cloned into pET-30. Two bacterial expression constructs $\left(\mathrm{pET}-1 \mathrm{~S}^{\mathrm{sh}} \mathrm{x} 2.9\right.$ and $\mathrm{pET}-1 \mathrm{~S}^{\mathrm{sh}} \mathrm{y} 2.3$ ) were chosen to express mature protein in bacterial cells. In the cells harboring $\mathrm{pET}-1 S^{\mathrm{sh}} \mathrm{x} 2.9$ and $\mathrm{pET}-1 \mathrm{~S}^{\mathrm{sh}} \mathrm{y} 2.3$, IPTG induction led to the expression of the protein bands with electrophoretic mobility similar to those of the native $\mathrm{x}$ and $\mathrm{y}$-type subunits from the seed extract of Ae. sharonensis (Figure 2).

\section{Structural characteristics of primary sequences of Aegilops HMW-GSs}

We predicted the amino acid sequences of six Sitopsis HMW-GSs and found that their primary structures are composed of four regions, i.e. a signal peptide, a central repetitive domain, the conserved $\mathrm{N}$-terminal and C-terminal. The distribution and number of cysteine residues are identical to those in typical $x$-type and $y$-type subunits (Figure 3, 4; Table 2). The deduced protein sequences were firstly aligned with other known HMW-GSs from A, $\mathrm{B}$ and D genomes. Such comparison demonstrated that there is a higher similarity between $\mathrm{S}$ and $\mathrm{D}$ genome. Therefore, we realigned the HMW-GSs identified from three Sitopsis accessions in this study with those encoded by $\mathrm{D}$ genome available in public databases to determine their evolutionary relationship (Figure 3,4). Our results indicated that the $\mathrm{S}$ genome-encoded glutenin subunits considerably differ from other known HMW-GSs. Compared to $1 \mathrm{Dx} 2$, Sitopsis $\mathrm{x}$-type subunits $\left(1 \mathrm{~S}^{\mathrm{b}} \mathrm{x} 2.9,1 \mathrm{~S}^{\mathrm{l}} \mathrm{x} 2.9\right.$ and $1 S^{\text {sh }}$ x2.9) share the insertion of 141 residue with five tripeptides, 15 hexapeptides and four nonapeptides (Figure 5a-c). For Sitopsis y-type subunits, both $1 S^{\mathrm{l}} \mathrm{y} 2.3$ and $1 S^{\text {sh }}$ y 2.3 have an insertion of 105 residues with seven hexapeptides and seven nonapeptides (Figure $5 \mathrm{~d}$ ), but this duplicated block in $1 S^{\mathrm{b}} \mathrm{y} 2.3$ only contains five hexapeptides and five nonapeptides (a total of 75 residues). We found that the peptide insertions in both $\mathrm{x}$-type and $\mathrm{y}$ type subunits from three Sitopsis species are copied from the adjacent regions, with some variations in single or more amino acid residues. 

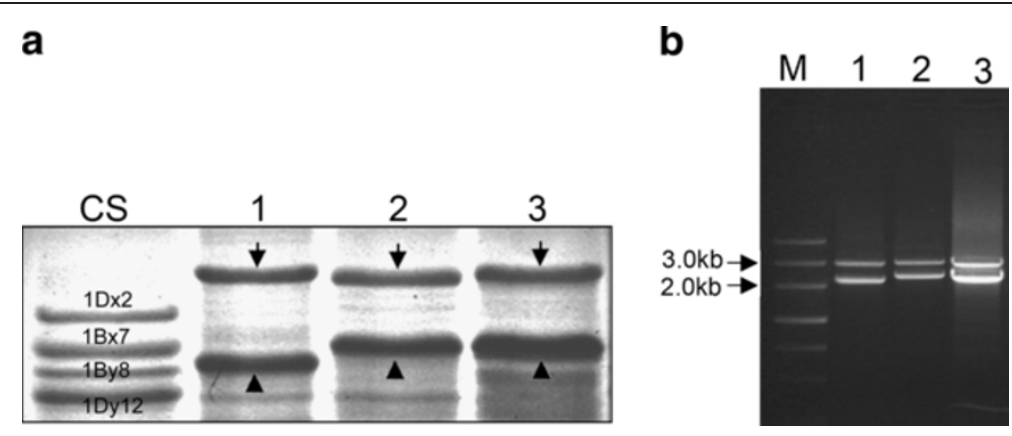

Figure 1 Characterization of HMW-GSs isolated from Aegilops sect. sitopsis species. (a) SDS-PAGE analysis revealed that both x-type and y-type HMW GSs (marked by arrow and triangle, respectively) are expressed in three Aegilops accessions and all six subunits have the molecular weights larger than those of Chinese Spring. (b) The complete DNA ORFs of both $\mathrm{x}$-type and y-type HMW-GSs were amplified from $\mathrm{S}$ genome. Lane 1, Ae. bicornis; Lane 2, Ae. longissima; Lane 3, Ae. sharonensis; CS, Chinese Spring; M is the 1 Kb DNA ladder.

\section{Structural characteristics of $5^{\prime}$ flanking promoters of Aegilops HMW-GSs}

The 5' flanking promoter regions of HMW-GS genes in three Sitopsis species were amplified by using two pairs of PCR primers specific to $\mathrm{x}$-type and y-type subunits, respectively. All amplified PCR products were cloned and sequenced. Based on previous studies, the promoter regulatory elements of HMW-GSs are composed of TATA box, complete and partial HMW enhancers, E and $\mathrm{N}$ motifs [26]. Our results indicated that the amplified promoter regions of Sitopsis HMW-GSs cover all recognized promoter regulatory elements. The DNA lengths of $1 S^{b} \times 2.9,1 S^{l} \times 2.9$ and $1 S^{\text {sh }} \times 2.9$ promoter are identical (904 bp); whereas those of $1 S^{b} y 2.3,1 S^{l} y 2.3$ and
$1 S^{\text {sh }} y 2.3$ varied from $845 \mathrm{bp}$ to $919 \mathrm{bp}$. The characterized promoter sequences of Sitopsis $\mathrm{x}$-type and y-type HMW-GSs were aligned to homologous regions of $1 A x 2 * 1 B x 7,1 D x 2$, Triticum urartu 1Ay, 1By9 and 1Dy10, respectively. Multiple sequence alignments showed that both types of glutenin subunits encode the conserved domains and variable parts in their promoter regions. We found that the HMW-GS promoters mainly differentiate with base substitutions, insertions, or deletions (data not shown). All the regulatory elements in the characterized Sitopsis HMW-GS promoters share the high conservation with few substitutions (Table 3). An 85 bp fragment, in which the partial HMW enhancer was included, was deleted in the 5 ' flanking promoter

Table 1 Comparison of the $\boldsymbol{N}$-terminal amino acid sequences derived from protein sequencing with those deduced from the cloned DNA sequences encoding for HMW-GS in three Aegilops species

\begin{tabular}{|c|c|c|c|c|c|c|c|c|c|c|c|c|c|}
\hline \multirow[t]{2}{*}{ Species } & \multirow[t]{2}{*}{ Subunit } & \multicolumn{12}{|c|}{ Residue } \\
\hline & & 1 & 2 & 3 & 4 & 5 & 6 & 7 & 8 & 9 & 10 & 11 & 12 \\
\hline Triticum aestivum & x-type consensus & $\mathbf{E}$ & G & $\mathbf{E}$ & A & $\mathbf{S}$ & G/E & $\mathbf{Q}$ & $\mathbf{L}$ & $\mathbf{Q}$ & $C$ & $\mathbf{E}$ & $\mathbf{R} / \mathrm{H}$ \\
\hline \multirow[t]{2}{*}{ Ae. bicornis } & $1 S^{b} \times$ sequenced & $E$ & $G$ & $E$ & $A$ & $S$ & $G$ & $Q$ & $\mathrm{~L}$ & Q & $C$ & $E$ & $\mathrm{R}$ \\
\hline & $1 S^{b} x$ deduced & $E$ & $G$ & $E$ & $A$ & $S$ & $G$ & $Q$ & $L$ & $Q$ & C & $E$ & $\mathrm{R}$ \\
\hline \multirow[t]{2}{*}{ Ae. longissima } & $1 S^{\prime} \times$ sequenced & $E$ & $G$ & $E$ & A & $S$ & $G$ & $Q$ & $L$ & Q & C & & \\
\hline & $1 S^{\prime} x$ deduced & $E$ & $G$ & $E$ & A & $S$ & $G$ & $Q$ & $L$ & Q & C & $E$ & $\mathrm{R}$ \\
\hline \multirow[t]{2}{*}{ Ae. sharonensis } & $15^{s h} \times$ sequenced & $E$ & $G$ & $E$ & A & $\mathrm{S}$ & $G$ & Q & $\mathrm{L}$ & Q & C & $E$ & \\
\hline & $1 S^{s h} x$ deduced & $E$ & $G$ & $E$ & $A$ & $S$ & $G$ & $\mathrm{Q}$ & $\mathrm{L}$ & $\mathrm{Q}$ & $C$ & $E$ & $\mathrm{R}$ \\
\hline T. aestivum & y-type consensus & $\mathbf{E}$ & $\mathbf{G}$ & $\mathbf{E}$ & A & $\mathbf{S}$ & $\mathbf{R} / \mathbf{K}$ & $\mathbf{Q}$ & $\mathbf{L}$ & $\mathbf{Q}$ & C & $\mathbf{E}$ & $\mathbf{R}$ \\
\hline \multirow[t]{2}{*}{ Ae. bicornis } & $1 \mathrm{~S}^{\mathrm{b}} \mathrm{y}$ sequenced & $E$ & $G$ & $E$ & $A$ & $S$ & $\mathrm{R}$ & $Q$ & $L$ & $Q$ & $C$ & $E$ & $\mathrm{R}$ \\
\hline & $1 S^{b} y$ deduced & $E$ & $G$ & $E$ & $A$ & $S$ & $\mathrm{R}$ & $Q$ & $L$ & $Q$ & $C$ & $E$ & $\mathrm{R}$ \\
\hline \multirow[t]{2}{*}{ Ae. longissima } & 1S'y sequenced & $E$ & $G$ & $E$ & $A$ & $\mathrm{~S}$ & $\mathrm{R}$ & $Q$ & $L$ & $\mathrm{Q}$ & C & $E$ & \\
\hline & 1S'y deduced & $E$ & $G$ & $E$ & A & $S$ & $\mathrm{R}$ & Q & $L$ & Q & C & $E$ & $\mathrm{R}$ \\
\hline \multirow[t]{2}{*}{ Ae. sharonensis } & $1 S^{s h} y$ sequenced & $E$ & G & $E$ & $A$ & $\mathrm{~S}$ & $\mathrm{R}$ & Q & $L$ & Q & C & $E$ & $\mathrm{R}$ \\
\hline & $1 S^{s h} y$ deduced & $E$ & $G$ & $E$ & $A$ & $S$ & $\mathrm{R}$ & $\mathrm{Q}$ & $L$ & $Q$ & $C$ & $E$ & $\mathrm{R}$ \\
\hline
\end{tabular}

The consensus sequences of $x$-type and y-type HMW subunits of bread wheat were also list as standard. The results indicated that the amino acid sequences translated from the cloned genes are perfectly matched to those of the native protein of seeds. 


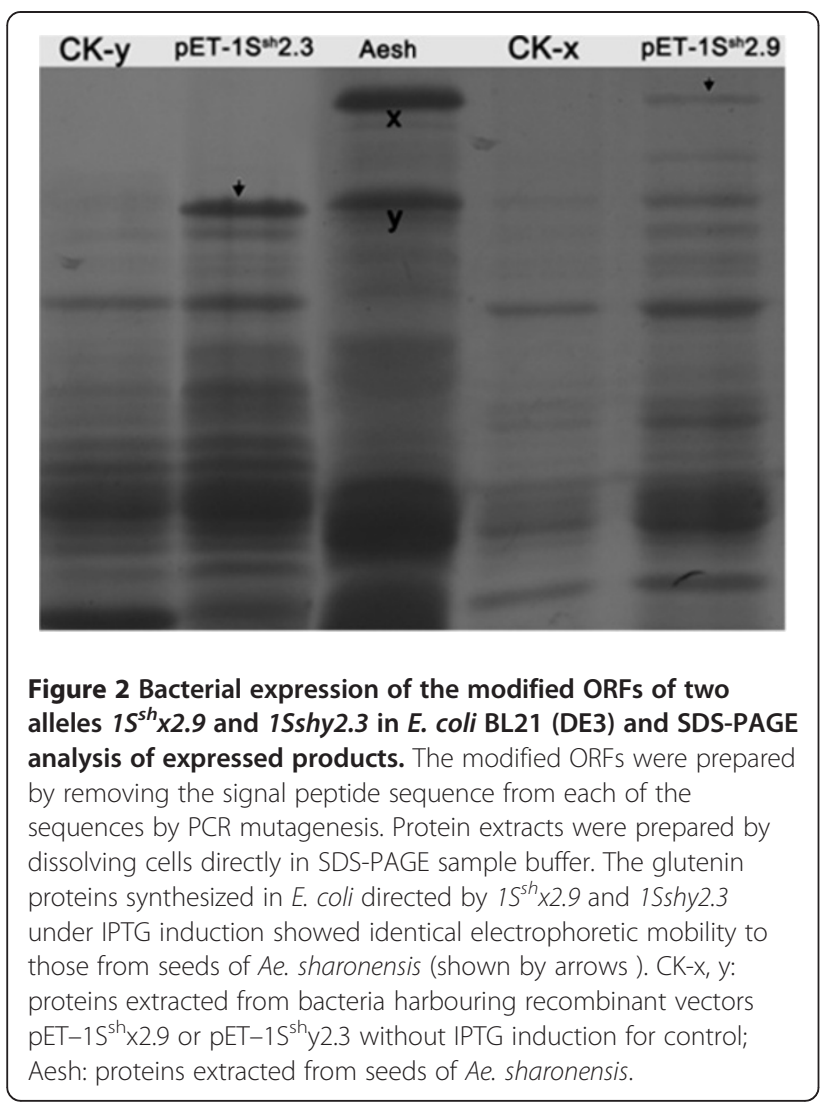

regions of $1 S^{\text {sh }} y 2.3$ (Table 3). This deletion has not interrupted the expression of $1 S^{\text {sh }} y 2.3$.

\section{Phylogenetic relationship of HMW-GSs between S and other genomes}

To investigate the evolutionary relationship between $S$ genome-encoded HMW-GS alleles and those of A, B, D genomes, we constructed the phylogeny of a network and a neighbor-joining tree (Figure 6a, b). The 5' flanking promoter sequences, plus the sequences encoding signal peptides and the N-terminal, were selected for phylogenetic analysis because they have demonstrated to be phylogenetically informative. Firstly, our previous study on HMW-GS promoter indicated that the regulatory elements which control the tissue specificity and expression level of different HMW-GS genes are well conserved in diploid species of Triticeae [27]. Secondly, the sequences encoding signal peptides and $\mathrm{N}$-terminal domain are also relative conserved. Therefore, these HMW-GS sequences were suitable for phylogenetic analysis $[17,28]$.

Our network analysis demonstrated that all HMW-GS alleles are clustered into two groups ( $x$-type and $y$-type subunits) (Figure 6a). Both $x$-type and y-type subunits showed a star-like phylogeny from principle nodes. In the $\mathrm{x}$-type group, $1 S^{l} \times 2.9$ and $1 S^{\text {sh }} \times 2.9$ are linked to
$1 S^{b} \times 2.9$, and then form a close link to the principle node which is composed of $1 D x 2,1 D \times 2.2$ and $1 D \times 2.2 \%$. For the y-type group, $1 S^{b} y 2.3,1 S^{l} y 2.3$ and $1 S^{\text {sh }} y 2.3$ are formed a parallel link to the $y$-type genes encoded by D genome. The resulted NJ tree also indicated that $x$-type and y-type subunits are divided into two clades which support a close phylogenetic relationship on HMW-GSs between $\mathrm{S}$ and D genome (Figure 6b). Therefore, our results from both network and neighbor-joining tree demonstrated that $\mathrm{S}$ genome-encoded HMW-GS alleles are evolutionally related to those of $\mathrm{D}$ genome.

\section{Discussion}

As HMW-GSs play the key role in determining wheat gluten and dough elasticity, the characterization on novel HMW-GSs from Triticeae wild germplasm will be beneficial not only for improving wheat end-use quality but also for further understanding the structure variation and evolution of this important protein family. Compared to bread wheat, wild Triticeae grasses have more HMW-GS variants. For example, a number of HMWGS variants with novel structural characteristics have been identified from Aegilops genus [16,18,29]. However, the progress on characterizing the HMW-GS expression from Aegilops section Sitopsis species remains slow and our knowledge on their structure, function, and evolution is still limited. In this study, we report the isolation and characterization of six x-type and y-type HMW-GSs variants from the $\mathrm{S}$ genome of three Aegilops species (Ae. bicornis, Ae. longissima and Ae. sharonensis). These novel variants will be useful to widen or enrich Glu-1 genes and HMW-GSs for wheat quality breeding.

\section{Structural variations and evolution of Glu-S1 alleles and possible mechanism}

To avoid the potential error in PCR or sequencing, each nucleotide sequence was determined by multiple independent clones. The results of $\mathrm{N}$-terminal sequencing indicated that the first 10 residues of $\mathrm{N}$-terminal protein sequence of all $6 \mathrm{x}$ and $\mathrm{y}$-types subunits deduced from DNA sequences match perfectly to those directly determined by protein sequencing. And further bacterial expression proved that the cloned sequences are indeed accurate representations of the coding genes of HMWGS in three Aegilops species. Therefore, the molecular information for Glu-S1 alleles obtained in this study is reliable and suitable for exploring structural differentiation and evolution of Glu-S1 alleles. Our results demonstrated that each of three Aegilops section Sitopsis species has two expressed subunits and the possession of large molecular weights is unique in both $x$-type and y-type subunit of $S$ genomes $\left(S^{\mathrm{b}}, S^{\mathrm{l}}\right.$ and $S^{\text {sh }}$ ). Previous study reported that $1 \mathrm{Dx} 2.2^{*}$ and $1 \mathrm{Dx} 2.2$ are the largest HMW-GSs and their mature subunits contain 1003 and 
950 amino acid residues, respectively [25,30]. In this study, we identified that the length of Ae. sharonensis subunit $1 S^{\text {sh }} \times 2.9$ is 953 residues, shorter than $1 \mathrm{Dx} 2.2^{\text {* }}$ but longer than $1 \mathrm{Dx} 2.2$, which means $1 S^{\mathrm{sh}} \times 2.9$ is the second largest HMW-GSs characterized so far (Table 2). In addition, $1 S^{\mathrm{b}} \times 2.9$ of Ae. bicornis and $1 S^{\mathrm{l}} \times 2.9$ of $\mathrm{Ae}$. longissima also have large molecular weights close to that of 1Dx2.2. For y-type HMW-GS genes, the lengths of their complete ORFs are usually less than $2 \mathrm{~kb}$. Our previous study reported that a HMW-GS gene variant $1 A y$ (Ta-e3), isolated from einkorn wheat, encodes its ORF with the length of $2202 \mathrm{bp}$, larger than all other known y-type genes [17]. In this study, however, we identified two novel y-type Glu-1 alleles, $1 S^{l} y 2.3$ from Ae. longissima and $1 S^{\text {sh }} y 2.3$ from Ae. sharonensis, and determined that their ORF lengths are 2256 and $2242 \mathrm{bp}$, respectively, much larger than that of $1 A y$ (Ta-e3) (Table 2). As the y-type HMW-GS genes with such large molecular weights have not been reported in wheat and its related species, both $1 S^{l} y 2.3$ and $1 S^{\text {sh }} y 2.3$ will be special and useful to extend our knowledge on structure, function, evolution of the y-type HMW-GSs.

Four modes have been proposed for the sequence alteration and evolution of HMW-GSs: (1) single residue changes, (2) deletion or insertion in a repeat unit, (3) single repeat changes, and (4) deletions or duplications of repeat blocks [6]. It has been reported that the unequal crossover events and slip-mismatching are the most likely mechanism of the size variations in HMWGSs $[25,31]$. In this study, we found that the large molecular weights of $\mathrm{S}$ genome-encoded subunits are almost entirely due to the insertion and duplication of these repeat motifs (Figure 3, 4). Previous study on comparative analysis of peptide sequences indicated that 1Dx2.2 and 1Dx2.2* are evolved from the two separate duplications of 132 and 186 residues, respectively [30]. Although three $\mathrm{S}$ genome-encoded $\mathrm{x}$-type subunits, $1 \mathrm{Dx} 2.2$ and $1 \mathrm{Dx} 2.2^{*}$ have been resulted from duplication events, they are different in three ways. Firstly, each duplication of $1 \mathrm{Sx}$ subunits, $1 \mathrm{Dx} 2.2$ and $1 \mathrm{Dx} 2.2^{*}$ occur at different positions of repetitive domains (Figure $5 \mathrm{a}$-d; Table 4). Secondly, the duplicated regions contain the varied numbers of repeat motifs which result in distinct size of inserted fragments among $1 \mathrm{Sx}$ subunits, 1Dx2.2 and 1Dx2.2* Thirdly, the inserted fragments from duplications in $1 \mathrm{Sx}$ subunits are not completely identical to that from which it was duplicated (Figure 7). On the contrary, the new inserted regions in $1 \mathrm{Dx} 2.2$ and 1 Dx2.2* are perfect copy of adjacent region without any changes. Based on above discussions, we can conclude that Sitopsis x-type subunits, 1Dx2.2 and 1Dx2.2* may have independent origins, although they share the similar evolutionary mode. We realized that such similar pattern also exists in the $\mathrm{S}$ genome-encoded $\mathrm{y}$-type subunits.

\section{Implications of novel Aegilops HMW-GSs for wheat quality breeding}

Two structural features of HMW-GSs may be relevant to their participation as gluten polymers in the baking quality of dough. Firstly, the number and distribution of cysteine residues determine the forming inter- and intra-molecular disulphide bonds. It is well known that disulphide bonds play a key role in determining the structure and properties of wheat glutenin polymers. The presence of an additional cysteine residue in the repetitive region of subunit $1 \mathrm{Dx} 5$ was reported to be responsible for the correlation of this particular HMW-GS with good bread-making quality $[32,33]$. We found that the $\mathrm{S}$ genome-encoded subunits have the conserved cysteine composition, which may be important to keep the normal gluten polymer. Secondly, the properties and interactions of repetitive domains are important in determining the dough viscoelastic properties [34]. The positive relationship between the HMW-GS sizes and their effects on dough strength has been revealed by previous studies. Belton [35] and Feeney et al. [36] proposed a model in which the gluten polymers interact via inter-chain hydrogen bonds between the subunit repetitive domains and more stable interactions can be formed with longer subunits. The experiments of incorporating the 1Dx2.2 and 1Dx2.2*subunits into dough indicated that both subunits can lead to yield the dough strength greater than 1Dx2. As both $x$-type and y-type subunits encoded by the $S$ genome are larger than almost all other known HMW-GSs, we predict that the S genome-encoded HMW-GSs may have an outstanding ability to strengthen the gluten interactions. Based on our results, it will be valuable to further explore the potential values of these novel Sitopsis HMWGS variants in modifying the structure, composition and function of wheat storage proteins. Furthermore, these special S genome-encoded genes and glutenin subunits will be helpful to overcome the bottleneck of poor genetic diversity of Glu-1 alleles and HMW-GSs in hexaploid wheat. Two approaches are under the way to verify the function of $1 \mathrm{Sx}$ subunits. One is to develop wheat transgenic plants which allow the endosperm specific expression of $1 \mathrm{Sx}$ alleles; the other is to transfer the 1Sx subunits to tetraploid or hexaploid wheats by the interspecies cross. 


\begin{tabular}{|c|c|}
\hline 1Dy10 & MAKRLVLF AAVVIALVALTT A \\
\hline 1Dy10.1 & MAKRLVLFAAVVIALVALTT AFGEASRQLQCERELQESSLEACRQVVDQQLAGRPPWSTGLQMRCCQQLRDVSAKCRSVAVSQVARQYEQ 90 \\
\hline 1Dy12 & MAKRLVLF AAVVIALVALTT AEGEASRQLQCERELQESSLEACRQVVDQQL AGRLPWSTGLQMRCCQQLRDVSAKCRSVAVSQVARQYEQ 90 \\
\hline $1 S^{9} \mathrm{y} 2.2$ & MAKRLVLF ATVVT ALVALTT AFGE ASRQLQCERELQESSLEACRQVVDQQL AGRLPWSTGLQMRCCQQLRDVSTKCRPVAVSQVARQYEQ 90 \\
\hline $1 \mathrm{~s} y 2.3$ & AKRLVLF ATVVTALVALTT AEGE ASRQLQCERELQESSLEACRQVVDQQL AGRLPWSTGLQMRCCQQLRDVSAKCRPVAVSQVARQYEQ 90 \\
\hline $1 \mathrm{~S}^{\text {sh }} \mathrm{y} 2.3$ & MAKRLVLFATVVTALVALTTAEGEASRQLQCERELQESSLEACRQVVDQQL AGRLPWSTGLQMRCCQQLRDVSAKCRPVAVSQVARQYEQ 90 \\
\hline 1Dy10 & WVPPKGGSFYPGETTPLQQLQQGIF WGTSSQTVQGYYPGVTSPRQGSYYPGQASPQQPGQGQQPGKWQEPGQGQQWYYPTSLQQPGQGQ 180 \\
\hline 1Dy10.1 & TVVPPKGGSFYPGETTPLQQLQQGIFWGTSSQTVQGYYPSVTSPRQGSYYPGQASPQQPGQGQQPGKWQEPGQGQQWYYPTSLQQPAQGQ 180 \\
\hline 1Dy12 & TVVPPKGGSFYPGETTPLQQLQQGIF WGTSSQTVQGYYPSVTSPRQGSYYPGQASPQQPGQGQQPGKWQEPGQGQQWYYPTSLQQPGQGQ 180 \\
\hline $1 \mathrm{~S}^{\mathrm{b}} \mathrm{y} 2.2$ & TVVLPKGESFYPGE TTPLQQLQQGIF WGTSSQTVQGYYPSVTSPRQGSYYPGQASPQQPGQGQQPGKWQELGQGQQGYYPTSLQQPGQGQ 180 \\
\hline $15 y 2.3$ & TMVLPKGGSFYPGETTPLQQLQQGIF WGTSSQIVQGYYPSVTSPRQGSYYPGQASPQQLGQGQQPGKWQEPGQGQQGYYPTSLQQPGQGQ 180 \\
\hline $1 \mathrm{~S}^{\mathrm{sh}} \mathrm{y} 2.3$ & TMVLPKGGSF YPGE TTPLQQLQQG IF UGTSSQIVdGYYPSVTSPRQGSYYPGQASPQQLGQGQQPGKWQEPGQGQQGYYPTSLQQPGQGQ 180 \\
\hline 1Dy10 & QIGKGQQGYYPTSLQQPGQGQQ------GYYPTSLQHTGQRQQPVQGQQ------PEQGQQPGQWQQGYYPTSPQQLGQGQQPRQWQQSG 258 \\
\hline 1Dy10.1 & KQGYYPTSLQQPGQGQQIGQGQQGYYPTSPQHTGQRQQPVQGQQIGQGQQPEQGQQPGQWQQGYYPTSPQQLGQGQQPGC \\
\hline 1Dy12 & QIGKGKQGYYPTSLQQPGQGQQIGQGQQGYYPTSPQHTGQRQQPVQGQQIGQGQQPEQGQQPGQWQQGYYPTSPQQLGQGQQPGQWQQSG 270 \\
\hline $1 S^{b} \mathrm{y} 2.2$ & QIGKGQQGYYPTSLQQPGQGQQIGQGQQGYYPTSPQHPGQRQQPVQGQQIGQGQQLEQGEQPGQWQQGYYPTSPQQLGQGQEPGQWQQSG 270 \\
\hline 1 Sty2.3 & QIGKGQQGYYPTSLQQPGQGQQIGQGQQGYYPTSPQHPGQRQQPVQGQQIGQGQQLEQGEQPGQWQQGYYPTPPQQLGQGQEPGRWQQSG 270 \\
\hline $1 \mathrm{~S}^{\text {sh }} \mathrm{y} 2.3$ & QIGKGQQGYYPTSLQQPGQGQQIGQGQQGYYPTSPQHPGQRQQPVQGQQIGQGQQLEQGEQPGQWQQGYYPTPPQQLGQGQEPGQWQQSG 270 \\
\hline 1Dy1 & GHYLASQQQPGQGQQGHYP ASQQQPGQGQQGH \\
\hline 1Dy10.1 & QGQQGHYPTSLQQPGQGQQGHYL ASQQQP AQGQQGHYP ASQQQPGQGQQGHYP ASQQQPGQ---GHYP ASQQEPGQGQQGQIP ASQQQPG 357 \\
\hline $1 \mathrm{Dy} 12$ & QGQQGHYPTSLQQPGQGQQGHYL ASQQQP AQGQQGHYP ASQQQPGQGQQGHYP ASQQQPGQGQQGHYP ASQQEPGQGQQGQIP ASQQQPG 360 \\
\hline $1 S^{b} \mathrm{y} 2.2$ & QGQQGHYP ISL $Q Q P G Q G Q Q G H Y L A S Q Q Q P G Q G P Q G H Y P A S Q Q Q P G Q G Q Q G H Y P A S Q Q Q P G Q G Q Q G H Y P A S Q Q E P G Q G Q Q G K I P$ ASQQQPG 360 \\
\hline $1 \mathrm{~s} y 2.3$ & QGHYL ASQQQPGQGPQGHYP ASQQQPGQGQQGHYP ASQQQPGQGQQGHYP ASQQEPGKGQQGQIP ASQQQPG 360 \\
\hline $1 \mathrm{~S}^{\text {shy } y 2.3}$ & QGRQGHYPTSLQQPGQGQQGHYL ASQQQPGQGPQGHYP ASQQQPGQGQQGHYP ASQQQPGQGQQGHYP ASQQEPGKGQQGQIP ASQQQPG 360 \\
\hline 1Dy & 382 \\
\hline 1Dy10.1 & - 389 \\
\hline 1Dy12 & 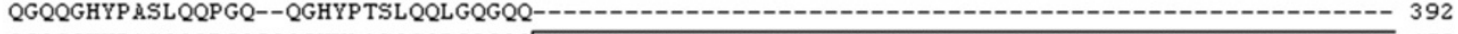 \\
\hline $1 S^{b} y 2.2$ & QGQQGHYP ASQQQPGQGQQGHYL ASQQQPGQGQQ GHYP ASQQQPGQGQQGHYP ASQQEPGQGQQGQIP ASQQQPGQGQQGHYPTSLQQPG 450 \\
\hline $1 \mathrm{sy} 2.3$ & QGKQGHYP ASLQQPGQGQQGHYL ASQQQPGQGQQ GHYP ASQQQPGQGQQGHYP ASQQQPGQGQQGHYP ASQQQPGQGQQGHYP ASQQEPG 450 \\
\hline $1 \mathrm{~S}^{\text {sh }} \mathrm{y} 2.3$ & QGKQGHYP ASLQ----GQQGHYL ASQQQPGQGQdGHYP \&SQQQP GQGQQGHYP ASQQQPGQGQQGHYP ASQQQP GQGQQGHYP ASQQEPG 446 \\
\hline 1Dy1 & --TGQPGQKQQPGQGQQTGQGQQPEQEQQPGQGQQGYYPTSLQ 423 \\
\hline & -IGQPGQKQQPGQGQQTGQGQQPEQEQQPGQGQQGYYPTSLQ 430 \\
\hline 1Dy12 & 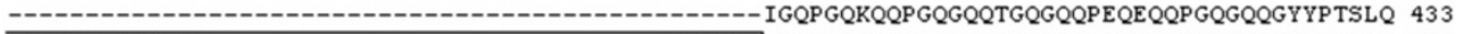 \\
\hline $1 S^{b} y 2.2$ & 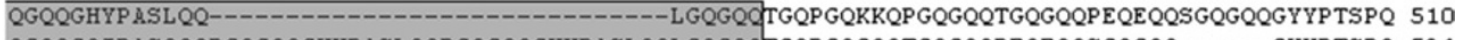 \\
\hline $15 y 2.3$ & QGQQGQIP ASQQQP GQGQQGHYP ASLQQPGQGQQGHYP ASLQQLGQGQQTGQPGQGQQTGQGQQPEQEQQSGQGQQ------GYYPTSPQ 534 \\
\hline & QGOOGOIPASOOOPGOGOOGHYPASLOOPGOGOOGHYPASLOOLGOGOOTGQPGLGQQTGQGQQPEQEQQSGQGQQ------GYYPTSPQ 530 \\
\hline
\end{tabular}

1Dy10

$10 y 10.1$

1 Dy12

QPGQGQQQGQGQQ------GYYPTSLQQPGQGQQGHYP ASLQQPGQGQ--PGQRQQPGQGQHPEQGKQPGQGQQGYYPTSPQQPGQGQQL 505 QPGQGQQQGQGQQ------GYYPTSLQQPGQGQQGHYP ASLQQPGQGQ--PGQRQQPGQGQHPEQGQQPGQGQQGYYPTSPQQPGQGQQL 512 QPGQGQQQGQGQQ------GYYPTSLQQPGQGQQGHYP ASLQQPGQGQGQPGQRQQPGQGQHPEQGQQPGQGQQGYYPTSPQQPGQGQQL 517 QPGQGQQQGQGQQ------GYYPTSLQQPEKGQQGHYP ASLQQPGQGH--PGQRQQPGQGQHPEQEQQPGQGKQGYYPTSPQQ-------L 586 LPGQGQHQGQGQQQGQGQQGYYPTSLQQPEKGQQGHYP ASLQQPGQGQ--PGQRQQPGQGQHPEQEQQPGQGQQGYYPTSPQQPGQGQQL 622 LPGQGQHQGQGQQQGQGQQGYYPTSLQQSEKGQQGHYP ASLQQPGQGR--PGQRQQPGQGQHPEQEQQPGQGQQGYYPTSPQQPGQGQQL 618

1 S'y 2.3

$1 S^{\text {shy }}$ 2.3

1Dy10

$10 y 10.1$

$1 \mathrm{Dy} 12$

$1 S^{b} y 2.2$

$1 \mathrm{~S} y 2.3$

$1 S^{\text {shy }} \mathbf{2 . 3}$

GQGQQGYYPTSPQQPGQGQQPGQGQQGHCPTSPQQSGQRQQPGQGQQIGQVQQ------PGQGQQGYYPTSVQQPGQGQQSGQGQQSGQG 589 GQGQQGYYPTSPQQPGQGQQPGQGQQGHCPTSPQQTGQRQQPGQGQQIGQVQQ------PGQGQQGYYPTSLQQPGQGQQSGRGQQSGQG 596 GQGQQGYYPTSPQQPGQGQQPGQGQQGHCP MSPQQTGQRQQLGQGQQIGQVQQ-------PGQGQQGYYPTSLQQPGQGQQSGQGQQSGQG 601 GQGQQGYYPTSPQHAGQGQQPGQGQQGRCPTSLQQTGQAQQPGQGQQIGQVQQPGQVQQPGQGQQGYYPTSLQQPGQGQQSGQGQQSGQG 676 GQGQQGYYPTSPQQEGQGQQPGQGQQGRCPTSLQQTGQRQQPGQGQQIGQVQQPGQVQQPGQGQQGYYPTSLQQPGQGQQSGQGQQSGQG 712 GQGQQGYYPTSPQQEGQGQQPGQGQQGRCSTSLQQTGQAQQPGQGQQIGQVQQPGQVQQPGQGQQGYYPTSLQQPGQGQQSGQGQQSGQG 708

1DY10 HQPGQGQQSGQEQQ FYDSPYHVSAEQQAASPIVARAQQPATQLPTVCRMEGGDALSASQ 648

1DY10.1 HQPGQGQQSGQEQOGYDSPYHVSAEQQAASPNVAKAOQP ATQLPTVCRMEGGD ALSASO 655

$10 y 12$ HQPGQGQQSGQE KQ GYDSPYHVS AEQQAASP MV AKAQQP ATQLPTVCRMEGGD ALSASQ 660 HQPGQEQQSGQE KQ GYDSPYHVSAEQQAASSHVAKAQQPTTQLTTVCRMEGGDALSASQ 735

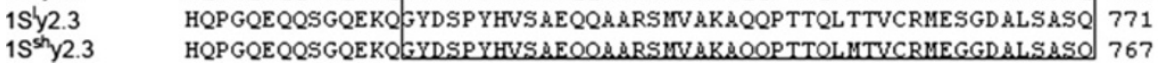

Figure 4 Sequence comparison of $\mathbf{y}$-type HMW-GSs isolated from D and S genomes. The comparison of $y$-type subunits indicated that the insertions in $15 y$ subunits have never been identified and characterized in other known subunits. 
Table 2 Comparison of primary structures of HMW-GSs

\begin{tabular}{|c|c|c|c|c|c|c|c|c|}
\hline & Number of & 0 acid residu & & & Number of & ine residues & & \\
\hline & $\begin{array}{l}\mathrm{N} \text {-terminal } \\
\text { domain }\end{array}$ & $\begin{array}{l}\text { Repetitive } \\
\text { domain }\end{array}$ & $\begin{array}{l}\text { C-terminal } \\
\text { domain }\end{array}$ & Total & $\begin{array}{l}\mathrm{N} \text {-terminal } \\
\text { domain }\end{array}$ & $\begin{array}{l}\text { Repetitive } \\
\text { domain }\end{array}$ & $\begin{array}{l}\text { C-terminal } \\
\text { domain }\end{array}$ & Total \\
\hline $1 \mathrm{~A} \times 2^{*}$ & 86 & 666 & 42 & 794 & 3 & 0 & 1 & 4 \\
\hline $1 \mathrm{~B} \times 7$ & 81 & 645 & 42 & 768 & 3 & 0 & 1 & 4 \\
\hline $1 \mathrm{D} \times 2$ & 88 & 687 & 42 & 817 & 3 & 0 & 1 & 4 \\
\hline $1 \mathrm{D} \times 2.1$ & 89 & 984 & 42 & 815 & 3 & 0 & 1 & 4 \\
\hline $1 \mathrm{D} \times 5$ & 89 & 687 & 42 & 818 & 3 & 1 & 1 & 5 \\
\hline $1 D \times 2.2$ & 89 & 819 & 42 & 950 & 3 & 0 & 1 & 4 \\
\hline $1 \mathrm{D} \times 2.2^{*}$ & 89 & 872 & 42 & 1003 & 3 & 0 & 1 & 4 \\
\hline $15^{b} \times 2.9$ & 86 & 816 & 42 & 944 & 3 & 0 & 1 & 4 \\
\hline $1 S^{1} \times 2.9$ & 86 & 816 & 42 & 944 & 3 & 0 & 1 & 4 \\
\hline $15^{\text {sh }} \times 2.9$ & 86 & 825 & 42 & 953 & 3 & 0 & 1 & 4 \\
\hline 1 Ay (Ta-e3) & 104 & 583 & 42 & 732 & 5 & 1 & 1 & 7 \\
\hline 1By9 & 104 & 538 & 42 & 684 & 5 & 1 & 1 & 7 \\
\hline 1Dy10 & 104 & 481 & 42 & 627 & 5 & 1 & 1 & 7 \\
\hline 1Dy12 & 104 & 493 & 42 & 639 & 5 & 1 & 1 & 7 \\
\hline $15^{b} y 2.3$ & 104 & 568 & 42 & 714 & 5 & 1 & 1 & 7 \\
\hline $1 S^{\prime} y 2.3$ & 104 & 604 & 42 & 750 & 5 & 1 & 1 & 7 \\
\hline $15^{\text {sh }}$ y 2.3 & 104 & 600 & 42 & 746 & 5 & 1 & 1 & 7 \\
\hline
\end{tabular}

The numbers of amino acid residues in bold are for large subunits.

\section{Conclusions}

We have identified and characterized six novel HMW-GS variants from three Aegilops section Sitopsis species. The possession of large molecular weights is unique feature of S genome-encoded HMW-GSs. These Sitopsis glutenin subunits with large molecular weights have been resulted from the similar duplication of repetitive domains as those in the subunits $1 \mathrm{Dx} 2.2$ and $1 \mathrm{Dx} 2.2^{*}$. The $\mathrm{S}$ genomeencoded subunits, 1Dx2.2 and 1Dx2.2\% have independent origins, although they share similar evolutionary mechanism. Because of their molecular weights much larger than all other known HMW-GSs, these novel Sitopsis glutenin subunits can be used as special genetic resources to improve wheat quality breeding.

\section{Methods}

\section{Plant materials}

Sixty-five accessions of Ae. bicornis, Ae. longissima and Ae. sharonensis, kindly provided by USDA-ARS (http://www. ars-grin.gov), were investigated on their HMW-GS profiles by using the SDS-PAGE. Three accessions (Clae 70 of $A e$. bicornis, PI 604122 of Ae. longissima and PI 584388 of Ae. sharonensis) with larger HMW-GS combinations were chosen for further cloning and characterization.

\section{SDS-PAGE and protein sequencing}

HMW-GSs of Ae. bicornis, Ae. longissima and Ae. sharonensis were extracted from the half of single seed according to Mackie et al. [37]. HMW-GSs from hexaploid wheat cv. Chinese Spring (null, 1Bx7+1By8, 1Dx2+ 1Dy12) were used as a standard reference for comparison of HMW-GS electrophoretic mobility. Total seed proteins were extracted in the sample buffer containing $0.0625 \mathrm{M}$ Tris- $\mathrm{HCl}(\mathrm{pH} 6.8), 2 \%(\mathrm{w} / \mathrm{v})$ SDS, $1.5 \%(\mathrm{w} / \mathrm{v})$ DTT, $10 \%$ (v/v) glycerol and 0.1\% w/v Coomassie Brilliant Blue R250. The extracts were heated at $95^{\circ} \mathrm{C}$ for $5 \mathrm{~min}$ and centrifuged for $10 \mathrm{~min}$. The supernatant was loaded onto a $10 \%$ (w/v) SDS-PAGE gel as described by Shewry et al. [2]. To ensure the experimental accuracy, at least three seeds were analyzed for each accession of these three Aegilops section Sitopsis species.

After electrophoresis, the proteins were transferred from the gel onto a PVDF (Poly vinylidene fluoride) membrane by western blotting. The membrane was saturated with methanol and stained with $0.1 \%(\mathrm{w} / \mathrm{v})$ Coomassie BBR250. The HMW subunit bands were then excised for protein sequencing. The N-terminal amino acid sequences of the HMW subunits were determined by GeneCore BioTechnology company (Shanghai, China) using the PROCI$\mathrm{SE}^{\mathrm{TM}}$ 494CLC amino acid sequencer of Applied Biosystems.

\section{Isolations and characterization of Sitopsis Glu-1 ORFs}

Genomic DNAs were extracted from the leaves of twoweek-old seedlings by using the CTAB method [38]. To amplify the complete coding regions of HMW-GSs, a pair of primers, P1 (5'-ATGGCTAAGCGGC/TTA/ 

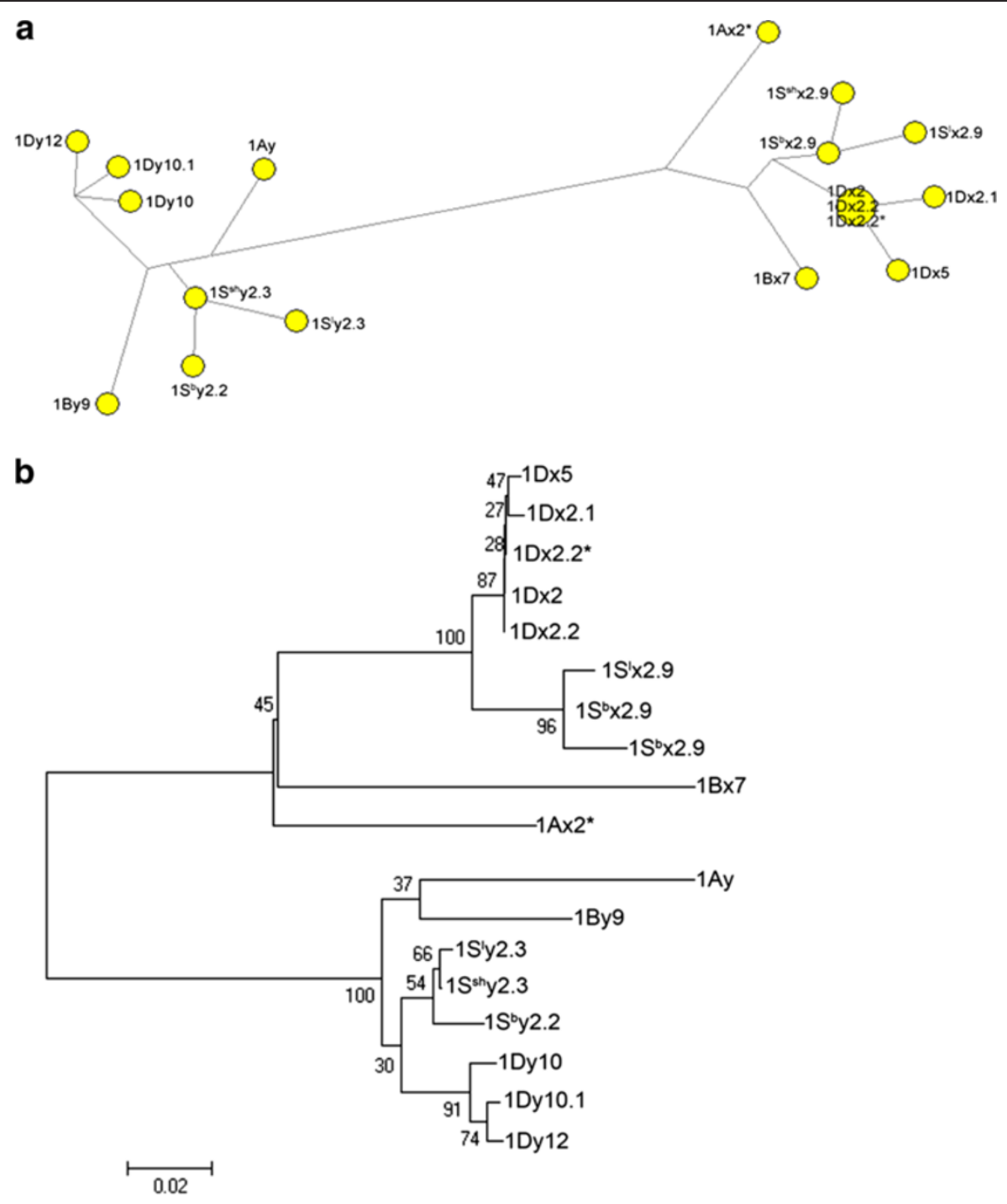

Figure $\mathbf{5}$ Schematic diagram of primary structure of large HMW-GSs from D and S genomes. The inserted fragments in (a) 1Dx2.2, (b) 1Dx2.2*, (c) 1Sx, and (d) 1Sy subunits are originated from independent duplication events. The new regions arose from block insertions are shown by the boxes and the length of each insertion is numbered in the box.

GGTCCTCTTTG-3') and P2 (5'-CTATCACTGGCTG/ AGCCGACAATGCG-3'), were designed according to nucleotide sequences in the conserved $5^{\prime}$ or $3^{\prime}$ ends of available HMW-GS ORF sequences. The high fidelity LA Taq polymerase (TaKaRa) with GC buffer for GCrich template was used in the PCR amplification to minimize the errors which were introduced into the sequences. The PCR cycling parameters was $94^{\circ} \mathrm{C}$ for $5 \mathrm{~min}$, followed by 30 cycles of $94^{\circ} \mathrm{C}$ for $40 \mathrm{sec}, 68^{\circ} \mathrm{C}$ for $5 \mathrm{~min}$ and a final extension step at $72^{\circ} \mathrm{C}$ for $12 \mathrm{~min}$ [39]. PCR products were separated in 1\% agarose gels and all DNA fragments were recovered, purified and further ligated into the pMD19-T vector (TaKaRa). The ligated mixtures were transformed into Escherichia coli DH5 $\alpha$ competent cells. The strategy of primer walking and the nest deletion method [40] were used to obtain the fulllength of Sitopsis Glu-1 ORFs. The DNA sequencing was performed by the Invitrogen Company (Shanghai, China). Each clone was sequenced in two directions, the final nucleotide sequences for each Glu-1 ORF was determined from the sequencing results of 3 independent clones.

\section{Bacterial expression of cloned HMW glutenin ORFs}

In order to confirm that the novel Glu-S1 genes expressed proteins that corresponded to those in the grain, we choose $1 S^{\text {sh }} \mathrm{x} 2.9$ and $1 S^{\text {sh }} \mathrm{y} 2.3$ as the representation of Glu-S1x and Glu-S1y for expressional experiments, as three pairs of $\mathrm{x}$ 
Table 3 Sequences variations of regulatory element among different HMW-GS promoters

\begin{tabular}{|c|c|c|c|c|c|c|}
\hline Alleles & $\begin{array}{l}\text { E motif } \\
\text { (TGTAACCC) }\end{array}$ & $\begin{array}{l}N \text { motif } \\
\text { (TGAGTCAT) }\end{array}$ & $\begin{array}{l}\text { Partial Enhancer } \\
\text { (TITGCAAA) }\end{array}$ & $\begin{array}{l}\text { Enhancer (GTTTTG CAAAGCTCCAATTGCTCCTT } \\
\text { GCTT ATCCAGCT) }\end{array}$ & $\begin{array}{l}\text { TATA box } \\
\text { (CTATAAAAG) }\end{array}$ & $\begin{array}{l}\text { Start } \\
\text { (TTATCA) }\end{array}$ \\
\hline $1 A \times 2^{*}$ & TGTAA $\underline{\mathbf{A T}} \mathrm{C}$ & TGAGTCAC & TTTGCAAA & GTTTI & CTATAAAAG & T두TCA \\
\hline $1 B \times 7$ & TGTAAAT C & TGAGTCAT & $\pi T G C \mathbf{G G A}$ & 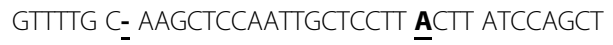 & CTATAAAAG & T스스 \\
\hline $10 \times 2$ & TGTAA $\underline{\mathbf{A} C C}$ & TGAGTCA $\underline{\mathbf{C}}$ & TITGCAAA & GTTTG CAAAGCTCCAATTGCTCCTT GCTTATCCAGCT & CTATAAAAG & TTATCA \\
\hline $10 \times 5$ & TGTAA $\underline{\mathbf{A} C C}$ & TGAGTCA $\underline{\mathbf{C}}$ & TITGCAAA & GTTTG CAAAGCTCCAATTGCTCCTT GCTTATCCAGCT & CTATAAAAG & TTATCA \\
\hline $15^{b} \times 2.9$ & TGTAA $\underline{\mathbf{A T}} \mathrm{C}$ & TGAGTCAC & TITGCAAA & 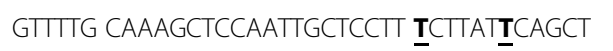 & CTATAAAAG & TㅅATCA \\
\hline $15^{\prime} \times 2.9$ & TGTAAATC & TGAGTCAC & TITGCAAA & GTTTG CAAAGCTCCAATTGCTCCTT $\underline{\mathbf{T} C T T A T \mathbf{T} C A G C T}$ & CTATAAAAG & TCATCA \\
\hline $15^{\text {sh }} \times 2.9$ & TGTAA $\underline{\mathbf{A T} C}$ & TGAGTCA $\underline{\mathbf{C}}$ & TITGCAAA & 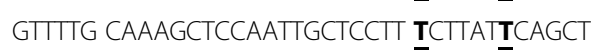 & CTATAAAAG & T스스 \\
\hline 1Ay & TGTAA $\underline{\mathbf{A T}} \mathrm{C}$ & $\underline{\mathbf{C}}$ GAGTCAT & deleted & GTTTG CAAAGCTCCAATTGCTCCTT GCTTATCCAGCT & CTATAAAAG & T스스 \\
\hline 1By9 & TGTAA $\underline{\mathbf{A T}} \mathrm{C}$ & TGAITCAT & $\mathrm{T} \underline{\mathbf{C}} T \underline{\mathbf{A}} \mathrm{CAAA}$ & GTTTG CAAA-ACTCCAATTGCTCCTT GCTTATCCAGCT & CTATAAAAG & T스스 \\
\hline 1Dy10 & TGTAA $\underline{\mathbf{A T}} \mathrm{C}$ & TGAGTCAT & TTTGCAAA & GTTTG CAAAGCTCCAATTGCTCCTT GCTTATCCAGCT & CTATAAAAG & 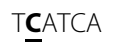 \\
\hline $15^{b} y 2.2$ & TGTAA $\underline{\mathbf{A} C C}$ & TGAGTCA $\underline{\mathbf{C}}$ & TTTGCAAA & GTTTG CAAAGCTCCAATTGCTCCTT GCTTATCCAGCT & CTATAAAAG & 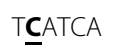 \\
\hline $1 S^{\prime} y 2.3$ & TGTAA $\underline{\mathbf{A T}} \mathrm{C}$ & TGAGTCAT & TTTGCAAA & GTTTG CAAAGCTCCAATTGCTCCTT GCTTATCCAGCT & CTATAAAAG & TTATCA \\
\hline $15^{s h} y 2.3$ & TGTAAATC & TGAGTCAT & deleted & GTTTG CAAAGCTCCAATTGCTCCTT GCTTATCCAGCT & CTATAAAAG & TCATCA \\
\hline
\end{tabular}

The position of each variation is underlined in the corresponding locus of consensus sequences.

and y-type genes possess highly similar DNA sequences and molecular mass in Ae. bicornis, Ae. longissima and Ae. sharonensis. To express of the mature proteins of HMW-
GS from Ae. sharonensis, we designed two pairs of primers for amplifying the mutant ORF from which the sequence coding for signal peptide was removed and introducing
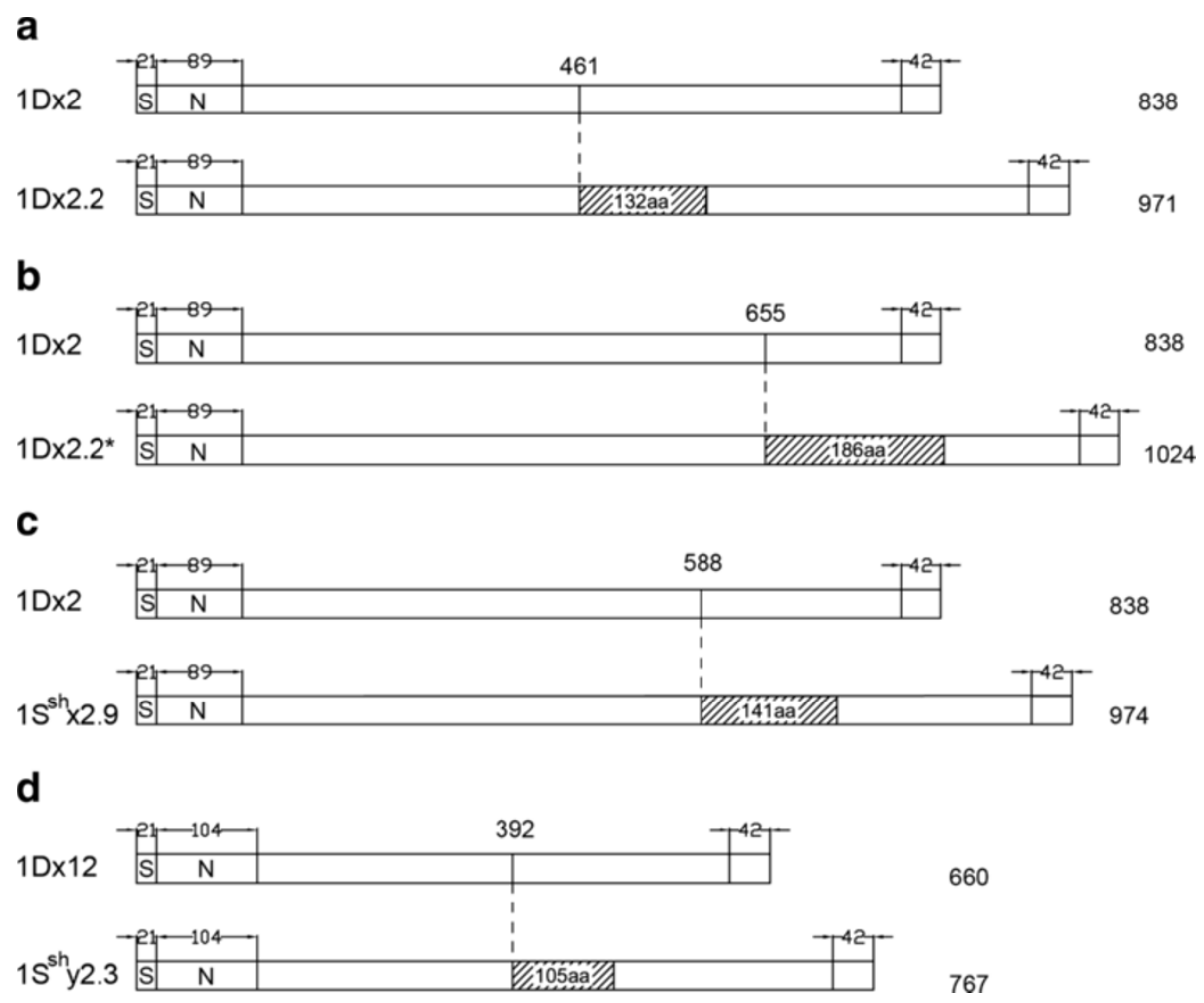

Figure 6 Evolutionary relationship between HMW-GSs alleles of S genomes and those of Glu-A1, Glu-B1 and Glu- D1. Phylogenetic analysis was constructed from nucleic acid sequence variations of the $5^{\prime}$ flanking promoter sequences, plus the sequences encoding the signal peptides and N-terminal regions. Both the network (a) and the neighbor-joining (b) tree indicated that all HMW-GS alleles are clustered into two groups (x-type and y-type subunits) which strongly support the close relationship between $\mathrm{S}$ genome HMW-GS alleles and those of D genome. 
Table 4 Repetitive motifs of the inserted fragments in repetitive domains of $\mathbf{S}$ genome-encoded HMW-GSs identified in this study and those of previously characterized one

\begin{tabular}{|c|c|c|c|c|}
\hline Subunit & $\begin{array}{l}\text { Number } \\
\text { of } \\
\text { tripeptide }\end{array}$ & $\begin{array}{l}\text { Number } \\
\text { of } \\
\text { hexapeptide }\end{array}$ & $\begin{array}{l}\text { Number } \\
\text { of } \\
\text { nonapeptide }\end{array}$ & $\begin{array}{l}\text { Total number } \\
\text { of amino } \\
\text { acid residues }\end{array}$ \\
\hline $1 \mathrm{D} \times 2.2$ & 4 & 14 & 4 & 132 \\
\hline $1 \mathrm{D} \times 2.2^{*}$ & 8 & 21 & 4 & 186 \\
\hline $15^{b} \times 2.9$ & 5 & 15 & 4 & 141 \\
\hline $1 S^{\prime} \times 2.9$ & 5 & 15 & 4 & 141 \\
\hline $15^{\text {sh }} \times 2.9$ & 5 & 15 & 4 & 141 \\
\hline $15^{b} y 2.3$ & 0 & 5 & 5 & 75 \\
\hline $1 S^{\prime} y 2.3$ & 0 & 7 & 7 & 105 \\
\hline $15^{\text {sh }} y 2.3$ & 0 & 7 & 7 & 105 \\
\hline
\end{tabular}

appropriate restriction enzyme sites of NdeI and EcoRI for the mutant ORF to facilitate following cloning and expression. The primers pairs of PET-F1 (CTCACCCATATG GAAGGTGAGGCCTCTGGGCA) and PET-R1 (GGCAA TGAATTC CTATCACTGGCTAGCCGACA) were used to amply $1 S^{\text {sh }} \times 2.9$ while the combination PET-F2 (CTCA TCCATATGGAAGGTGAGGCCTCTAGGCA) and PETR2 (GGCAAT GAATTCCTATCACTGGCTGGCCGACA) were specific for y-type genes of $1 S^{\text {sh }} y 2.3$. PCR conditions for amplifying mutant ORF were identical to those described above except that the template was plasmid DNA purified from the determined clones. After the mutant ORF was cloned into the expression vector pET-30a (Novagen), the recombinant construct was selected to express mature protein in the E. coli strain BL21 (DE3). Induction of bacterial expression was performed with $1 \mathrm{mM}$ IPTG for 3 to 5 hours. The expressed proteins were purified by extraction with $50 \%(\mathrm{v} / \mathrm{v})$ propanol containing $2 \%$ $(w / v)$ DTT, and then separated by SDS-PAGE [18].

Isolations and characterization of the $5^{\prime}$ flanking promoters of HMW-GSs

Two pairs of primers were designed for amplifying promoter regions for both $\mathrm{x}$-type and $\mathrm{y}$-type glutenin subunits in these three Aegilops section Sitopsis species. The P3 primer (5'-AGGGAAAGACAATGGACATG -3') was designed from the sequence which was strictly conserved

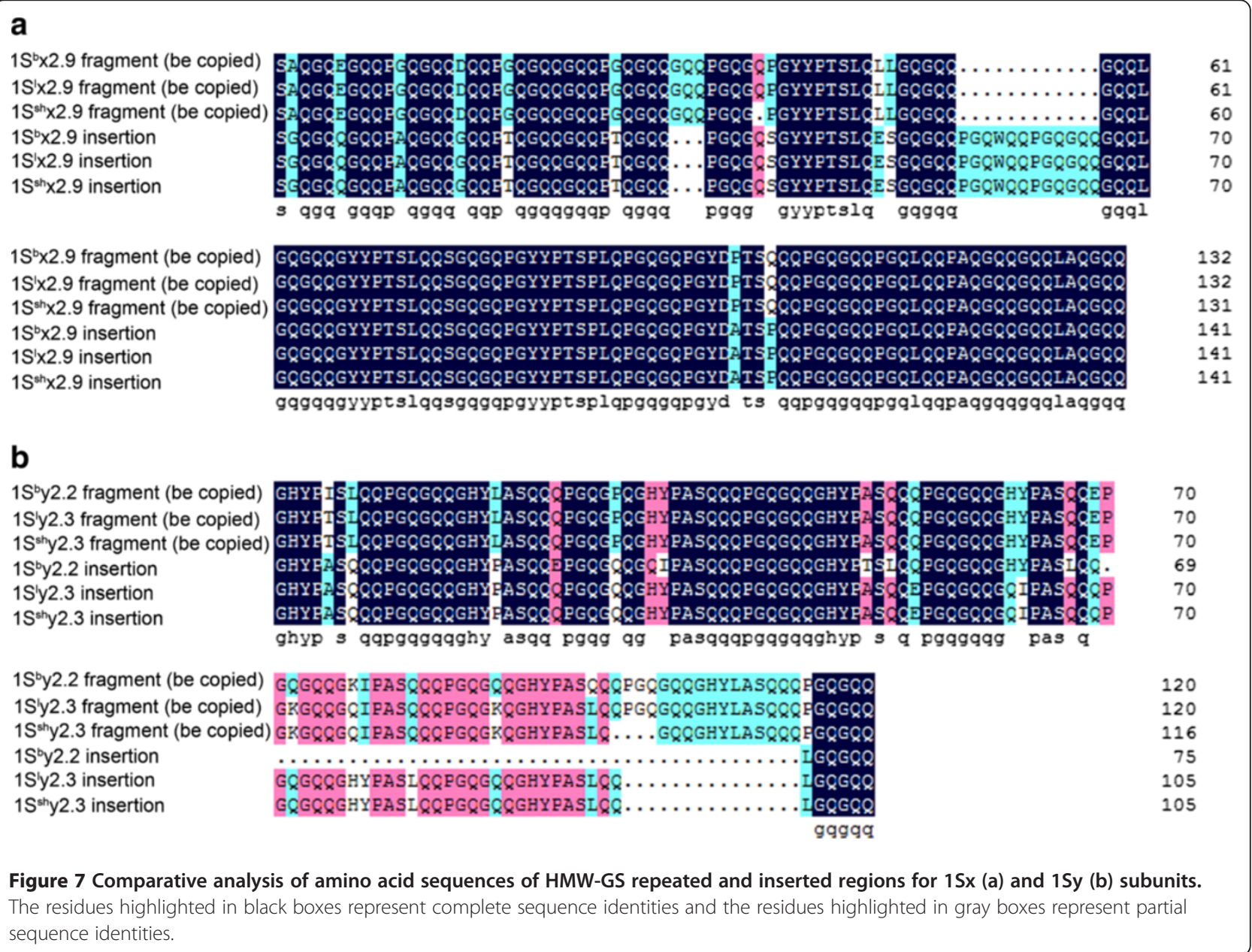


in the 5 ' flanking regions of all Glu-1 loci, whereas the primer P4 (5'-GTCTCGGAGC/T TGC/TTGGTC-3') and primer P5 (5'-CATCTGGAGCCCCGTGCTC-3') was derived from the sequence coding for 6 residues (DQQLRD) and (STGLQM), respectively. Each of sequence residues exists only in $\mathrm{x}$-type and y-type HMW-GSs, respectively. The primer combinations $\mathrm{P} 3+\mathrm{P} 4$ and $\mathrm{P} 3+\mathrm{P} 5$ are specific for $\mathrm{x}$-type and $\mathrm{y}$-type promoters. The amplification profile was $94^{\circ} \mathrm{C}$ for $5 \mathrm{~min}$, followed by 35 cycles of $94^{\circ} \mathrm{C}$ for $40 \mathrm{sec}, 60^{\circ} \mathrm{C}$ for $1 \mathrm{~min}$, and $72^{\circ} \mathrm{C}$ for $1 \mathrm{~min} 30 \mathrm{sec}$, and a final extension step at $72^{\circ} \mathrm{C}$ for $7 \mathrm{~min}$. PCR products were purified, cloned into pMD19-T, and then sequenced. The final nucleotide sequences for Glu-1 promoters were also constructed from sequencing at least 3 independent clones.

\section{Sequence analyses and phylogenetic investigation}

The prediction of nucleotide sequences was performed by the DNAman software package (V5. 2. 10; Lynnon Biosoft). Multiple alignments were carried out by using Clustal W (V1.83) for comparisons of either DNA or protein sequences [41]. Alignments were further improved by visual examination and manual adjustment. To characterize the phylogenetic relationship of HMW-GS genes, we compared the S genome-encoded Glu-1 alleles from these three Aegliops section Sitopsis species with previously characterized $\mathrm{x}$-type HMW-GSs alleles represented by 1Ax2* (M22208), 1Bx7 (X13927), 1Dx2 (X03346), 1Dx5 (X12928), 1Dx2.1 (AY517724), 1Dx2.2 (AY159367), $1 D \times 2.2 *$ (AY893508), and also with previously characterized y-type HMW-GSs represented by $1 A y$ (EU984508), 1By9 (X61026), 1Dy10 (X12929), 1Dy12 (X03041) and 1Dy10.1 (AY695379). The 5' flanking promoter sequences, plus the sequences encoding signal peptides and the N-terminal, which is considered as phylogenetically informative [28], were selected to create a multiple alignment by the Clustal W program. All the nucleotide sequences and their alignments have also been listed as supplementary materials (see Additional files 1, 2 and 3). The neighbour-joining (NJ) tree was constructed by using the software MEGA 4.02 with the substitute model of Maximum Composite Likelihood [42]. In the NJ analysis, gaps were treated as missing data. The bootstrap values were calculated based on 1000 replications to estimate the topological robustness. For the network analysis, the sites with base substitution or mutation were used to constructed media-joining network in program Network 4.6.0.0 (http://www.fluxus-engineering.com/). The media-joining network was calculated under the default parameters of weights $=10$ and epsilon $=0$ [43].

\section{Additional files}

Additional file 1: Full alignment of y-type HMW-GS ORF sequences of Aegilops species with those encoded by D genome. Description: The similarity was showed by different color. The deletions were showed by gaps.

Additional file 2: Full alignment of x-type HMW-GS ORF sequences of Aegilops species with those encoded by D genome. Description: The similarity was showed by different color. The deletions were showed by gaps.

Additional file 3: Full alignment of promoter sequences of Aegilops species with those of Glu-A1, Glu-B1 and Glu-D1. Description: The similarity was showed by different color. The deletions were showed by gaps.

\section{Author contributions}

JQT contributed to design and carry out the experiments and wrote the draft; MJ did the cloning of HWM glutenin ORFs; WYM revised the manuscript; LYX and LXJ made contribution to SDS-PAGE analysis and promoter cloning; LZX conducted the analysis of the data and review the manuscript; ZS and ZQZ finished the cloning of promoter, phylogenetic analysis and bacterial expression; ZYL contributed to improve research program. All authors have read and approved the final manuscript.

\section{Acknowledgement}

This work was supported by the National Natural Science Foundation of China (31000167 and 31171556), the National High Technology Research and Development Program of China (863 program 2011AA100103), the National Basic Research Program of China (973 Program 2010 CB134400) and China Transgenic Research Program (2011ZX08002).

\section{Author details}

${ }^{1}$ Triticeae Research Institute, Sichuan Agricultural University, Chengdu, Sichuan 611130, China. 'Lethbridge Research Centre, Agriculture and AgriFood Canada, Lethbridge T1J 4B1, Canada. ${ }^{3}$ Key Laboratory of Southwestern Crop Germplasm Utilization, Ministry of Agriculture, Sichuan Agricultural University, Ya'an, Sichuan 625014, China.

Received: 19 September 2011 Accepted: 11 May 2012 Published: 30 May 2012

\section{References}

1. Payne Pl: Genetics of wheat storage proteins and the effect of allelic variation on breadmaking quality. Ann Rev Plant Physiol 1987, 38:141-153.

2. Shewry PR, Tatham AS, Barro P, Lazzeri P: Biotechnology of breadmaking: unraveling and manipulating the multi-protein gluten complex. Nat Biotech 1995, 13:1185-1190.

3. Payne PI, Holt LM, Krattiger AF, Carrillo JM: Relationship between seed quality characteristics and HMW glutenin composition determined using wheats grown in Spain. J Cereal Sci 1988, 7:229-235.

4. Lawrence GJ, Shepherd KW: Chromosomal location of genes controlling seed proteins in species related to wheat. Theor App/ Genet 1981, 59:25-31.

5. Anderson OD, Abraham-Pierce FA, Tam A: Conservation in wheat highmolecular-weight glutenin gene promoter sequences: comparisons among loci and among alleles of the Glu-B1-1 locus. Theor Appl Genet 1998, 96:568-576.

6. Anderson OD, Greene FC: The characterization and comparative analysis of high- molecular-weight glutenin genes from genomes $A$ and $B$ of a hexaploid bread wheat. Theor Appl Genet 1989, 77:697-700.

7. Forde J, Malpica JM, Halford NG: The nucleotide sequence of an HMW glutenin subunit gene located on chromosome $1 \mathrm{~A}$ of wheat. Nucleic Acids Res 1985, 13:6817-6832.

8. Thompson RD, Bartels D, Harberd NP: Nucleotide sequence of a gene from chromosome 1D of wheat encoding a HMW glutenin subunit. Nucleic Acids Res 1985, 13:6833-6846.

9. Sugiyama T, Rafalski A, Peterson D, Soll D: A wheat HMW glutenin subunit gene reveals a highly repeated structure. Nucleic Acids Res 1985, 13:8729-8737.

10. Anderson OD, Greene FC, Yip RE, Halford NG, Shewry PR, MalpicaRomero JM: Nucleotide sequences of the two high-molecularweight glutenin genes from the D-genome of a hexaploid bread wheat Triticum aestivum L. cv Cheyenne. Nucleic Acids Res 1989, 17:461-462

11. Halford NG, Forde J, Anderson OD, Greene FC, Shewry PR: The nucleotide and deduced amino acid sequence of an HMW glutenin subunit gene 
from chromosome 1B of bread wheat (Triticum aestivum L.) and comparison with those of genes from chromosome 1A and 1D. Theor Appl Genet 1987, 75:117-126.

12. Liang D, Tang JW, Peña RJ, Singh R, He XY, Shen XY, Yao DN, Xia XC, He ZH: Characterization of CIMMYT bread wheats for high- and low-molecular weight glutenin subunits and other quality-related genes with SDSPAGE, RP-HPLC and molecular markers. Euphytica 2010, 172:235-250.

13. Liu SW, Gao X, Xia GM: Characterizing HMW-GS alleles of decaploid Agropyron elongatum in relation to evolution and wheat breeding. Theor Appl Genet 2008, 116:325-334.

14. Liu SW, Zhao SY, Chen FG, Xia GM: Generation of novel high quality HMW-GS genes in two introgression lines of Triticum aestivum/Agropyron elongatum. BMC Evol Biol 2007, 7:76.

15. Li ZX, Zhang XQ, Zhang HG, Cao SH, Wang DW, Hao ST, Li LH, Li HJ, Wang XP: Isolation and characterization of a novel variant of HMW glutenin subunit gene from the St genome of Pseudoroegneria stipifolia. J Cereal Sci 2008, 47:429-437.

16. Sun X, Hu S, Liu X, Qian W, Hao S, Zhang A, Wang D: Characterization of the HMW glutenin subunits from Aegilops searsii and identification of a novel variant HMW glutenin subunit. Theor App/ Genet 2006, 113:631-641.

17. Jiang QT, Wei YM, Wang F, Wang JR, Yan ZH, Zheng YL: Characterization and comparative analysis of HMW glutenin $1 A y$ alleles with differential expressions. BMC Plant Biol 2009, 9:16.

18. Wan YF, Wang DW, Shewry PR, Halford NG: Isolation and characterization of five novel high molecular weight subunit of glutenin genes from Triticum timopheevi and Aegilops cylindrical. Theor Appl Genet 2002 104:828-839.

19. Gianibelli MC, Larroque OR, MacRitchie F, Wrigley CW: Biochemical, genetic, and molecular characterization of wheat endosperm proteins. Cereal Chem 2001, 78:635-646.

20. van Slageren MW: Wild wheats: a monograph of Aegilops L. and Amblyopyrum (Jaub. \& Spach) Eig (Poaceae). Wageningen: Wageningen Agricultural University Press; 1994

21. Kihara $\mathrm{H}$ : Considerations on the evolution and distribution of Aegilops species based on the analyzer-method. Cytologia 1954, 19:336-357.

22. Yen Y, Kimber G: Genomic relationships of Triticum searsii to other S-genome diploid Triticum species. Genome 1990, 33:369-373.

23. Salina EA, Adonina IG, Vatolina TY, Kurata N: A comparative analysis of the composition and organization of two subtelomeric repeat families in Aegilops speltoides Tausch.and related species. Genetica 2004, 122:227-237.

24. Sasanuma T, Chabane K, Endo TR, Valkoun J: Characterization of genetic variation in and phylogenetic relationships among diploid Aegilops species by AFLP: incongruity of chloroplast and nuclear data. Theor Appl Genet 2004, 108:612-618.

25. D'Ovidio R, Lafiandra D, Porceddu E: Identification and molecular characterization of a large insertion within the repetitive domain of a high- molecular-weight glutenin subunit gene from hexaploid wheat. Theor Appl Genet 1996, 93:1048-1053.

26. Lamacchia C, Shewry PR, Fonzo ND, Forsyth JL, Harris N, Lazzeri PA, Napier JA Halford NG, Barcelo P: Endosperm-specific activity of a storage protein gene promoter in transgenic wheat seed. J Exp Bot 2001, 52:243-250.

27. Jiang QT, Wei YM, Wang JR, Yan ZH, Zheng YL: Molecular diversity and phylogenetic analyses of y-type high-molecular-weight glutenin promoters from different genomes in Triticeae. Plant Syst Evol 2010, 285:131-138.

28. Li W, Wan Y, Liu Z, Liu K, Liu X, Li B, Li Z, Zhang X, Dong Y, Wang D: Molecular characterization of HMW glutenin subunit allele 1Bx14: further insights in to the evolution of Glu-B1-1 alleles in wheat and related species. Theor Appl Genet 2004, 109:1093-1104.

29. Liu ZJ, Yan ZH, Wan YF, Liu KF, Zheng YF, Wang DW: Analysis of HMW glutenin subunits and their coding sequences in two diploid Aegilops species. Theor Appl Genet 2003, 106:1368-1378.

30. Wan YF, Yan ZH, Liu KF, Zheng YL, D'Ovidio R, Shewry PR, Halford NG, Wang D: Comparative analysis of the $D$ genome-encoded high molecular weight subunits of glutenin. Theor App/ Genet 2005, 111:1183-1190.

31. Payne PI, Lawrence GJ: Catalogue of alleles for the complex gene loci Glu-A1, Glu-B1 and Glu-D1, which code for the high-molecular-weight subunits of glutenin in hexaploid wheat. Cereal Res Commun 1983, 11:29-35.
32. Lafiandra D, D'Ovidio R, Porceddu E, Margiotta B, Colaprico G: New data supporting high Mr glutenin subunit 5 as determinant of qulity differences among the pairs 5+10 vs 2+12. J Cereal Sci 1993, 18:197-205

33. Gupta RB, MacRitchie F: Allelic variation of glutenin subunit and gliadin loci, Glu-1, Glu-3 and Gli-1 of common wheat. I. Its additive and interaction effects on dough properties. J Cereal Sci 1994, 19:9-17.

34. Shewry PR, Halford NG: Cereal seed storage proteins: structures, properties and role in grain utilization. J Exp Bot 2002, 53:947-958.

35. Belton PS: On the elasticity of wheat gluten. J Cereal Sci 1999, 29:103-109.

36. Feeney KA, Wellner N, Gilbert S, Halford N, Tatham A, Shewry P, Belton P. Molecular structures and interactions of repetitive peptides based on wheat glutenin subunits depend on chain length. Biopolym Biospectrosc 2003, 72:123-131.

37. Mackie AM, Lagudah ES, Sharp PJ, Lafiandra D: Molecular and biochemical characterization of HMW glutenin subunits from $T$. tauschii and the D genome of hexaploid wheat. J Cereal Sci 1996, 23:213-225.

38. Murray M, Thompson WF: Rapid isolation of high molecular weight plant DNA. Nucleic Acids Res 1980, 8:4321-4325.

39. Yan ZH, Wan YF, Liu KF, Zheng YL, Wang DW: Identification of a novel HMW glutenin subunit and comparison of its amino acid sequence with those of homologous subunits. Chinese Sci Bull 2002, 47:220-225.

40. Sambrook J, Fritsch EF, Maniatis T: Molecular cloning: a laboratory manual. New York: Cold Spring Harbor Laboratory Press; 1989.

41. Thompson JD, Higgins DG, Gibson TJ: CLUSTAL W: improving the sensitivity of progressive multiple sequence alignment through sequence weighting, position-specific gap penalties and weight matrix choice. Nucleic Acids Res 1994, 22:4673-4680.

42. Tamura K, Dudley J, Nei M, Kumar S: MEGA4: Molecular Evolutionary Genetics Analysis (MEGA) software version 4.0. Mol Biol Evol 2007, 24:1596-1599.

43. Allaby RG, Brown TA: Network analysis provides insights into evolution of 5 S rDNA arrays in Triticum and Aegilops. Genetics 2001, 157:1331-1341.

doi:10.1186/1471-2229-12-73

Cite this article as: Jiang et al:: Novel variants of HMW glutenin subunits from Aegilops section Sitopsis species in relation to evolution and wheat breeding. BMC Plant Biology 2012 12:73.

\section{Submit your next manuscript to BioMed Central and take full advantage of:}

- Convenient online submission

- Thorough peer review

- No space constraints or color figure charges

- Immediate publication on acceptance

- Inclusion in PubMed, CAS, Scopus and Google Scholar

- Research which is freely available for redistribution 